\title{
Committing to Trade Liberalisation in Australia
}

\author{
Gary Banks
}

$\mathrm{N}$

INTEEN NINETY SEVEN was an interesting year for those who thought the protection debate in Australia was over. Newspapers were full of speculation and opinion about the implications of the federal government's decisions on assistance to the motor vehicle (PMV) and textiles, clothing and footwear (TCF) industries. And a flurry of reports commissioned by the Department of Industry and industry lobby groups once again turned public and political attention to arguments for a more activist and selective industry policy. This interventionist push has clearly had some influence on the policy approaches of the government and, more particularly, the Labor opposition.

Although aspects of the current policy environment may give cause for concern, one can also find encouraging signs in the very vigour of the current debate. What we are in fact experiencing is the continuation of an approach to policy formulation that has some uniquely Australian characteristics. By and large the debate is relatively well informed and open, and the policy-making process is ultimately disciplined by a high degree of public scrutiny.

These observations indicate a theme of this article. Unlike most developed democracies, Australia has generally committed to its own trade liberalisation by sorting out the domestic implications in advance. It has experienced set-backs and side tracks along the way; it may do so again. But the direction of change has been underpinned by a relatively robust policy-making process in which the national interest has had ample opportunity to assert itself.

It is nevertheless important to reflect on what has driven Australia's reform efforts, in order not only to ensure that the conditions needed for further progress can be maintained, but also to consider how Australia's external trade policy might be more effective.

\section{Australia Has Come A Long Way}

Preoccupation with current developments can lead us to forget how far Australia has come. Useful reminders are provided by Max Corden (1996) in his 1995 Joseph Fisher lecture and by Richard Snape et al. (1998) in a documentary history of

Gary Banks is Executive Commissioner with the Industry Commission in Canberra. 
Australian trade policy, a valuable post-1965 sequel to Sir John Crawford's standard work (Crawford, 1968).

Figure 1 tells the story. Average 'net' assistance to the manufacturing sector has fallen from 36 per cent in the late 1960s (it may have been higher previously) to a projected 5 per cent in 2000 . Assistance to agriculture, while traditionally well below that for manufacturing, has also fallen - although it has played a more 'countercyclical' role and the numbers are not directly comparable. (The economywide costs of agricultural support, which goes mainly to the dairy industry, remain much lower than for manufacturing.) While equivalent historical data are not available for the mining sector, measures of its effective assistance have traditionally been negative. This penalty should have fallen significantly with the decline in manufacturing protection.

\section{Figure 1}

\section{Effective rates of assistance for agriculture and manufacturing, Australia 1969/90 - 2000/01}

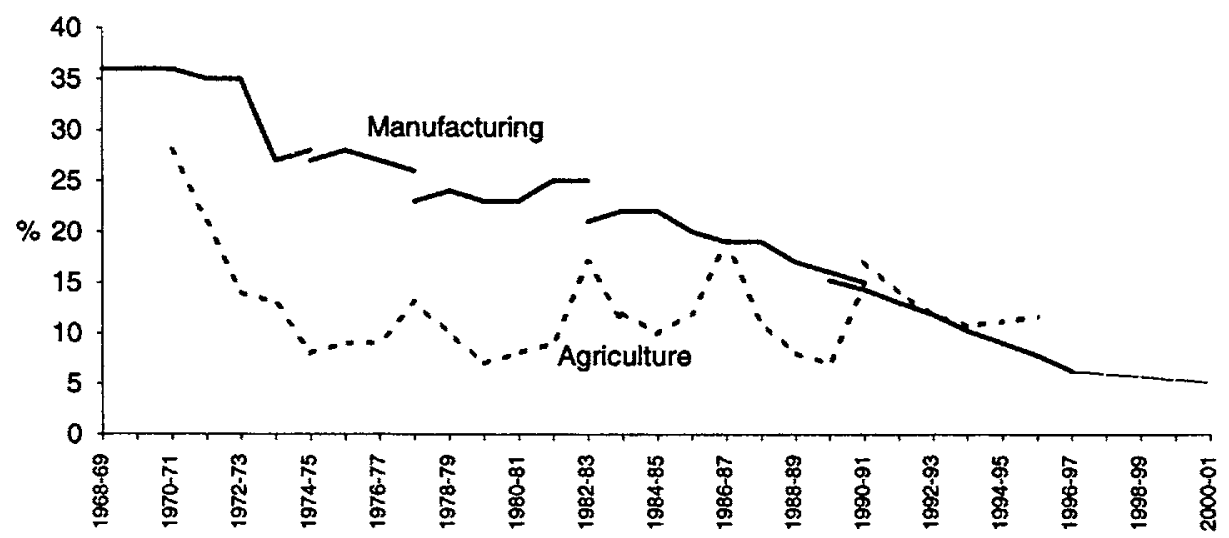

Note: Breaks in series represent re-calculation of cost structures, giving different estimates for value added and therefore different rates of assistance.

Source: IC (1995a; 1997c).

The liberalisation has been widespread among the various manufacturing industry groupings, and disparities in assistance have declined, as shown in Figure 2. It is also apparent, however, that assistance to the TCF and transport equipment sectors (which includes PMV) has been considerably more sustained than has been the case in other industries. These two sectors have been atypical, in that their assistance levels rose substantially in the decade after 1974. If the rates of assistance in 2000 - which are now finally 'locked in' - are compared with those in 1984, it be- 
comes apparent how much progress has also been made in these industries (shown in Figure 3).

\section{Figure 2}

Effective rates of assistance to selected industry groups, Australia, 1968/69 and 2000-01

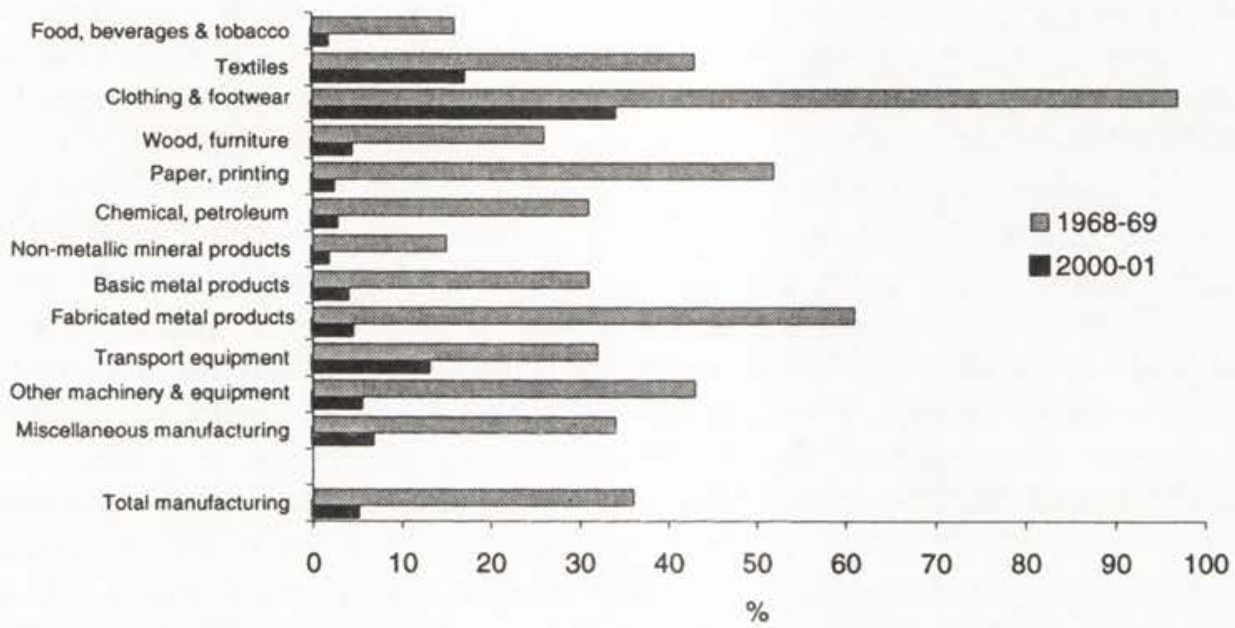

Source: IC (1995a).

Figure 3

The rise and fall of assistance to PMV and TCF, 1972-2001

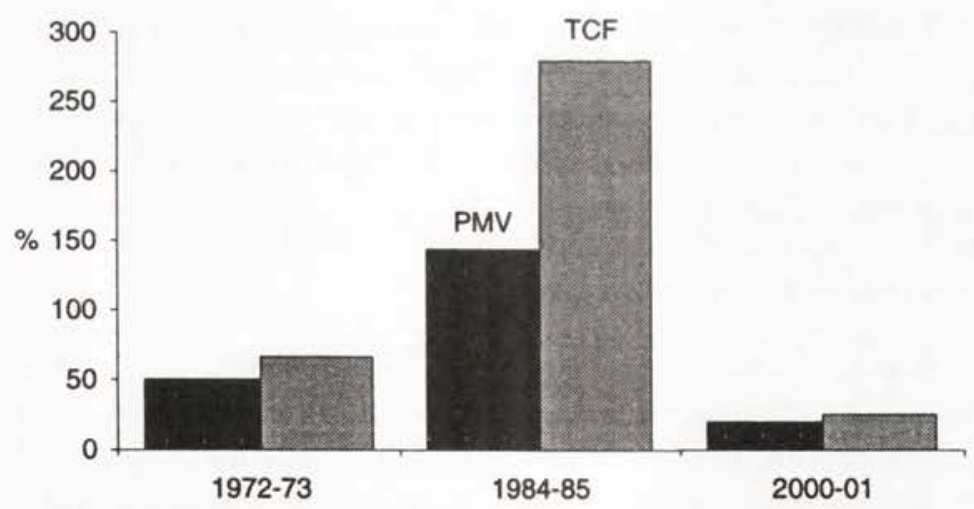

Source: IC (1995a). 
Of even greater significance than the lower assistance rates is the change in the form of delivery. Quantitative restrictions ('quotas') have finally been eradicated in favour of tariffs. Thus, the level of assistance has become more transparent and predictable, and the dynamics of foreign competition can generally flow more freely through the economy's price system.

Progress in reducing merchandise trade barriers has been accompanied by (and in some cases has precipitated) a range of other microeconomic reforms - in capital markets, public utilities, labour markets and other areas of regulation - which have exposed Australian producers of goods and services to greater competition, heightening incentives to be cost-conscious, innovative and productive. This has produced substantial benefits in lower prices, wider choice and higher incomes for Australians.

The policy-making environment today is also a great improvement on what it was in the 1960s. The oxymoron of 'protection all round', a phrase first coined by Earle Page, Treasurer in the Bruce Government of 1923-29, had become the guiding industry policy principle of that era. Consistent with that principle, tariffs were tailored to particular industries in a relentless quest by the Tariff Board to compensate domestic industries for their cost disadvantages - always provided, of course, that those industries were deemed 'economic and efficient' (as, it seems, most were). The tenor of the times is nicely captured by Max Corden's recent reflections on his earlier (1967) Fisher Lecture in which he, the epitome of an early economic rationalist, proposed the evolution of tariff-making towards nominal benchmarks of 30 per cent for new activities and 4.5 per cent for existing activities. As he observes, 'these were this free trader's very radical recommendations' (Corden, 1996:143.)

How did we get from there to here? In any other OECD country, the informed observer would point to the GATT (or other international trade forums). The GATT has indeed been the main vehicle for trade liberalisation activity by industrial countries. Yet it has played very little direct role in Australia's liberalisation. Moreover, the evidence suggests that the GATT's achievements elsewhere, while significant overall, have been seriously compromised in some sectors and suffered setbacks in others, especially when the rise of non-tariff measures (domestic subsidies, bilateral restraint agreements, anti-dumping and so on) is taken into account.

Dealing with these issues requires us to step outside the traditional approach to trade policy as an international issue, and to consider it as principally the outcome of domestic forces. To do this we need to confront some home truths about the political economy of protection.

\section{Biases in the Policy-Making Environment}

For trade liberalisation to involve meaningful commitments and durable progress, whether in goods or services trade, it must overcome a systemic protectionist bias in domestic policy-making environments. One well-recognised aspect of that bias flows from the uneven incentives facing those seeking assistance and those who eventually bear the burden of it to become informed and organise themselves to lobby government. This imbalance has been summed up as 'concentrated bene- 
fits, diffuse costs'. It is compounded by public sympathy for the protectionist arguments of industry, which reflects nationalism and notions of fairness, generally combined with a belief in the 'free lunch'. It is much easier to point to the industryspecific costs of reducing protection or other assistance (including job losses) than it is to understand its economy-wide benefits (including the jobs to come).

It is not so generally appreciated that this uneven pressure on governments to grant rather than remove protection can be compounded by the administrative and advisory mechanisms within government itself. The main source of advice available to government in responding to industries' claims is the bureaucracy. In most countries, the bureaucracy is divided into a few central agencies and numerous line departments, the latter being established to provide a communication link with interest groups. It is well known that in these departments symbiotic relationships naturally develop with their particular client groups. But even apart from this, sectorally oriented departments will tend to be inadequate as sources of information on industry assistance. They are too specialised and have too narrow a focus to be capable of properly evaluating the broader economic consequences. How much of a compounding effect this has depends on the scope within governmental decisionmaking processes for the economy-wide tradeoffs to be brought out. This is where central agencies and other advisory processes have a critical role.

Depending on how these 'supply-side' tensions work out, governments can find themselves being urged to respond to industry demands for assistance on the basis of partial information, in a political environment in which the majority of the electorate is either passive or supportive of protectionist claims.

\section{Role of the GATT/WTO}

The GATT was created with these national political and institutional pressures in mind. The unhappy trade policy experience of the 1930s and 1940 s convinced democratic governments that international commitments which constrained each country's freedom to 'beggar its neighbours' could also prevent governments from beggaring their own populations.

There are two sides to the role of the GATT (now the World Trade Organisation, WTO) in addressing the domestic political obstacles to reform. One is a set of international rules designed to provide stable and liberal (though not necessarily free) conditions of market access, based on the principles of non-discrimination and tariff-only protection. The other is a negotiating process, based on reciprocity, intended to create countervailing political forces to those domestic interests resisting liberalisation.

Unfortunately, the GATT did not work quite as intended. The rule of GATT law has suffered from the lack of an authoritative body to interpret and administer it (Tumlir, 1984), a defect that has been only partly addressed under the WTO. But a more practical difficulty is in the rules themselves, which are riddled with ambiguities, exceptions and exclusions, most of which reflect the interests of the very pressure groups they were designed to constrain. The two most notable casualties have been trade in agriculture and textiles. 
As well, the logic of reciprocity as a means of countering domestic resistance to liberalisation is flawed (Banks, 1990). The biggest drawback is that it has fostered mercantilist attitudes to liberalisation (Robertson, 1997). As the late Jan Tumlir from the GATT secretariat once noted, the original concept of collectively maximising benefits through reciprocal trade liberalisation has been debased over time to the point where:

liberal (free) trade is [considered] a good policy only if all countries practice it. This formulation now enables countries to use any failure of their trading partners to live up to the rules for justifying their own protectionist sins. (1983:6).

Thus, most countries have come to approach trade negotiations (and indeed the rules themselves) primarily as a vehicle for gaining access to foreign markets. Domestic liberalisation is regarded as a 'concession' - something to be minimised - rather than the most important source of benefit. It is little wonder, therefore, that negotiating rounds can take so long yet achieve so little in key areas, or that deals made in Geneva against pressing deadlines may be undone or circumvented by other forms of assistance in national capitals. Backsliding is inherent to the process.

The most telling instance of this (from Australia's perspective) coming out of the 1993 Uruguay Round was the agreement on agriculture. This contained, for the first time in the GATT, important liberalising principles of tariffication and reductions in assistance based on aggregate measures. But in practice it has involved little real liberalisation of agricultural trade because of the way the implementation modalities were subsequently manipulated (Gallagher, 1997).

The GATT's undoubted achievements have been the multilateralisation of international trade on a non-discrimination basis (creating order out of the preceding bilateralist chaos) and the substantial lowering of industrial tariffs by its industrialised members. The potential extension of core elements of liberal trade such as non-discrimination to trade in services has been a significant recent development. Against these achievements have been the protracted exclusion of sectors such as agriculture and textiles from the rules, and the rise of other forms of industry assistance that have compromised the gains from tariff reductions. Both phenomena have reflected the dominance of domestic vested interests over external process and commitments.

\section{International Agreements and Australian Liberalisation}

Like other countries, Australia has viewed the GATT much more as a means of getting better access to foreign markets than as a vehicle for facilitating domestic liberalisation. This remains largely true today. Thus, the last policy statement on trade by the previous government states that 'trade policy is about opening markets and business opportunities on the most favourable terms for Australian firms' (DFAT, 1995:6). And while the present government's White Paper on foreign and 
trade Policy (DFAT, 1997) makes a significant advance in acknowledging close links between trade policy and industry policy, it also clearly sees them as being on separate tracks.

From the outset, Australian governments typically have been wary of the potential for GATT rules and commitments to constrain their freedom to act. Richard Snape (1984) notes that Australia was not initially a supporter of the GATT's fundamental non-discrimination principle. He also notes that in 1956 Australia supported the US request for a GATT waiver, essentially placing that country's nontariff agricultural protection off-limits. The US waiver heralded the effective exclusion of agriculture from subsequent negotiating rounds.

Snape (1984:24) concludes his survey of Australia's relations with GATT thus:

It would appear that Australia has not yet really utilised the external constraints that are available from a commitment to the principles of the General Agreement and to its rounds of trade negotiations as a means to enable politicians to resist, in the general interest, the pressure of coalitions seeking the preservation or extension of protection for particular industries.

Australia's access-seeking attitude to the GATT also ensured that, in the absence of action on foreign barriers to agricultural trade, it made relatively few concessions of its own. It was not, of course, alone in this.

Table 1 decomposes the reduction in effective rates of manufacturing assistance shown in Figure 1, according to the main sources of change. Of the 31 percentage point net reduction in assistance since 1968-69, GATT negotiations accounted for roughly 3 percentage points (or one-tenth of the net reduction). The external contribution is even less significant when viewed in the context of all the rises and falls in assistance over that period.

Those negotiated reductions which Australia did make, in the context of the Tokyo Round, are the exceptions which prove the rule about its traditional approach to the GATT. They were based on a reference to the Industries Assistance Commission (IAC) which asked it to report confidentially (an unprecedented step) on those tariff reductions that could be made 'without any adverse employment or structural effects' (IAC, 1976). The request focused on reductions to eliminate the British preferential margin, as well as on reductions in already low tariffs. In the event, the reductions covered some 900 tariff items and their timing was triggered by the devaluation of the Australian dollar in November 1976. While they reduced the average rate of manufacturing assistance, their impact on efficiency was compromised by an associated increase in assistance disparities (IC, 1995a). Moreover, in the same period, Australia was busily increasing protection for its PMV, TCF and other sensitive industries - totally outside the ambit of the negotiations.

In the Uruguay Round, Australia simply sought and obtained credit for the 1988 and 1991 tariff reduction programs, although for a few tariff items larger reductions were agreed. Australia's commitments under the General Agreement on Trade in Services have required little liberalisation other than that which has 
emerged from domestic reform processes, and the extent of bound commitments is relatively small (IC, 1995b; 1996).

\section{Table 1}

Sources of change in manufacturing assistance, Australia, 1968/69 - 2000/01 (percentage points)

\begin{tabular}{|c|c|}
\hline July $197325 \%$ tariff cut & -8 \\
\hline January 1977 Tokyo Round & -3 \\
\hline PMV + TCF quotas ${ }^{a}$ & +10 \\
\hline TCF 1986 and other IAC reviews ${ }^{b}$ & -2 \\
\hline PMV 1988 & -2 \\
\hline Other (inc. from IAC reviews) ${ }^{\mathbf{c}}$ & $-s$ \\
\hline May 1988 program & -4 \\
\hline March 1991 program & -7 \\
\hline Export incentives ${ }^{\mathrm{d}}$ & +2 \\
\hline Bounties & + \\
\hline Change in industry structure ${ }^{\theta}$ & - \\
\hline Net total ${ }^{f}$ & -3 \\
\hline
\end{tabular}

Notes: ${ }^{a}$ Effects of increases in quota assistance to the PMV and TCF industries between the mid-1970s and the mid-1980s.

bEffects of post-1988 TCF plan, announced in November 1986, and phased tariff reductions for several other manufacturing industries (such as chemicals, plastics, paper and communications equipment) announced before the May 1988 program.

'Includes effects of the substantial depreciation of the Australian dollar in the mid-1980s on the assistance provided by volume quotas for PMV and TCF.

dEffects of increased use of export incentives and bounties from late-1970s to mid-1980s.

Effects of changes in the relative shares of industries within the manufacturing sector.

${ }^{\text {i }}$ Round figure.

Source: IC (1995a).

Apart from the GATT/WTO, two other external pressures for liberalisation have been the Closer Economic Relations agreement with New Zealand and the APEC liberalisation targets. The former has involved significant preferential reductions in tarifls, but little additional adjustment pressure, at least within the manufacturing sector (BIE, 1995). The latter, while achieving remarkable consensus at Bogor in 1994 on a schedule for the completion of 'free and open trade and investment in the Asia-Pacific', is a declaration of resolve and contains significant ambiguities. The apparent lack of concern of those representing the PMV and TCF sectors about the Bogor Declaration and their far greater concern about the Industry Commission's recommendations (which could be seen as simply putting the APEC commitment into effect) is indicative of the relative credibility of external and domestic processes in Australia. 


\section{Domestic Factors in Australia's Trade Liberalisation}

It follows that the factors driving reform in the Australian case have been almost wholly domestic in origin. The key development has been the increased capacity of policy-making processes to take an economy-wide view on industry assistance issues. Despite some setbacks, this view has increasingly prevailed over the piecemeal industry perspective which dominated in the 1960s and before. How this came about is a fascinating story in which politics, pressure groups, personalities, ideas, institutions and even intrigue all play a part, not to mention the role of timing and the influence of the business cycle.

Australia is clearly not the only country to have undertaken trade liberalisation outside an international negotiating framework. New Zealand and several of our Asian neighbours have also liberalised unilaterally, as have many developing countries in Latin America and, increasingly, Africa. The countries of Eastern Europe have also embarked on more fundamental economic reform. Nevertheless, some aspects of the Australian experience differentiate it from those other countries, and may make it more relevant to the developed countries that we are keen to see liberalise further. In particular, Australia has not experienced or faced economic collapse, or been under instructions from the International Monetary Fund, or even been subject to World Bank conditionality. As well, Australia has instituted a program of trade liberalisation through a bicameral parliamentary system.

One distinguishing feature of Australia's liberalisation path has been the role of the Industry Commission's predecessors, the Tariff Board and the IAC. Table 1 shows that, before the important general tariff phase-downs of 1988 and 1991, much of the liberalisation occurred following public inquiries by the IAC. Even the 25 per cent tariff cut of 1973, while having little in common with a public inquiry, had a direct connection to that institution through the formal advisory role played by its chairman. Perhaps more important, in the preceding years the Tariff Board undertook the ground work which, for the first time, began to make transparent the extent of protection to different manufacturing industries in Australia and its costs to consumers, exporting industries (especially rural interests) and those States that depended on primary production.

The authors who have studied the rise of this new perspective on protection policy appear to agree that there were three critical ingredients:

- the development of academic economic thinking on protection issues, and in particular of methodologies for measuring relative assistance levels and their efficiency implications, of which the world's leading exponent was Max Corden of the Australian National University;

\footnotetext{
IDetailed accounts are provided by Glezer (1982), Rattigan (1986), Anderson and Garnaut (1987) and, more recently, Garnaut (1994), Corden (1996) and the documentary history by Snape et al. (1998).
} 
- the existence of institutional vehicles that promoted the new thinking, the first being the Vernon Committee (which reported in 1965) and subsequently, and more durably, the Tariff Board; and

- what might be called the 'Rattigan Factor' (after Alf Rattigan, the last chairman of the Tariff Board and the first of the IAC): a chairman who could ensure that, in the face of strong internal and external opposition, the Board could meaningfully pursue the 'economic and efficient' criteria that were supposed to have been shaping its tariff recommendations.

Snape et al. (1998:21) use a battleground analogy to describe the early struggle to subject protection policy to economic reasoning:

On the one side were ranged many of the heavily protected industries and their industry associations, the Associated Chambers of Manufactures of Australia (ACMA), the Australian Industries Development Association (AIDA, which had grown out of the Australian Industries Protection League), and the Trade ministry; on the other were the Tariff Board, much of the economic press, most academic economists with interests in international trade, and primary industry organisations - though not the leadership of the political party which represented farmers, the Country Party. One of the main weapons of those in the freer trade camp was to bring the battle into the open. 'Public scrutiny' or 'transparency' of policy became the banner under which the Tariff Board and its successor, the IAC, were to fight. The Minister for Trade and Industry (J. McEwen) and the senior members of his department were clearly protectionist and were not keen to have the extent (and sometimes the procedures) of industry assistance publicly displayed.

In effect, the new Tariff Board was beginning to act as a public interest counterweight to the otherwise dominant influence of industries seeking assistance. It provided information about the extent and incidence of the costs of protection, which galvanised exporting interests and made their political advocacy more effective. For broadacre rural interests in particular, new meaning was given to the old expression 'riding on the sheep's back'. The 'protection all round' banner of their own party was revealed as the sham it had always been. Rural and mining interests thus became strong coalitions in support of trade liberalisation: not initially for reasons of trade bargaining with other countries, but because of the costs they were bearing from Australia's own import barriers.

Once the Board adopted a broader perspective in dealing with tariff issues, its semi-judicial characteristics of independence and transparency came into their own. This was recognised by Prime Minister Gough Whitlam who, in marked contrast to McEwen, declared himself a 'Rattigan man' and entrenched a national perspective 
in the legislation establishing the IAC in 1974. In the second reading speech, the Prime Minister emphasised:

The first and most important reason for establishing the Commission is to allow public scrutiny of the process whereby governments decide how much assistance to give different industries ... such a process must be independent and impartial, and seen to be independent and impartial ... (Snape et al., 1998:60)

The need for procedural and institutional counterweights to the clamour of vested interests was recognised by Whitlam, who saw protectionism as an obstacle to the efficiency and national wealth creation on which his social programs depended. The way in which the leader of the Country Party expressed his opposition to the new Commission merely served to underline the point:

What this means, of course, is the end of the long-established and successful system under which industry policy has been devised - the system of discussion, consultation and negotiation between industry and government. (D. Anthony, cited in Snape et al., 1998:63)

As is now well-known, it was not the end of such a system; it just made that system less exclusive and partial.

These observations should not be interpreted as suggesting that the IAC was the sole driver of liberalisation. Its role, after all, has only ever been to provide advice and information. Implementation required additional ingredients. For one thing, as Corden (1996) and Garnaut (1994) both note, the quality of bureaucratic advice and political advisers was important: a common factor also in the unilateral liberalisation initiatives of many developing countries. As well, from the outset, political leadership was a consistent factor in the more significant reforms. It is indeed the essential ingredient needed to make reform - and the adjustment it involves acceptable to the broader community, over the heads of the vocal minority who stand to lose from it.

Ross Garnaut (1994) stresses the broad educational program which helped to prepare a climate of opinion receptive to the sweeping liberalisation programs of 1988 and 1991. The latter occurred despite the onset of recession, an unprecedented event. It was announced in 1991 by Prime Minister Bob Hawke (Snape et al., 1998:5-6) thus:

The most powerful spur to greater competitiveness is further tariff reduction. Tariffs have been one of the abiding features of the Australian economy since Federation ... and the supposed virtues of this protection became deeply embedded in the psyche of the nation. But what in fact was the result? Inefficient industries that could not compete overseas; and higher prices for consumers and higher costs for our efficient primary pro- 
ducers. Worse still, tariffs are a regressive burden - that is, the poorest Australians are hurt more than the richest ... We have rejected the views of the so-called 'new protectionists' because they are simply proposing, in effect, the same discredited policies that had isolated our national economy from the rest of the world and caused the great damage we are all working to repair.

\section{'Backsliding' Australian-style}

As shown in the figures and table, Australia's liberalisation path over the past 30 years has not been all downhill. But Australia's policy reversals have generally been more explicit and transparent than elsewhere. The lack of external commitments has, with some exceptions, obviated the need for the kind of double game that most other developed countries have been playing with one another.

The first major policy reversal began little more than a year after the 25 per cent tariff cut in 1973. As Glezer (1982:125) has expressed it:

No government or agency attempting to change the structure of Australian industry at a pace faster than the industries themselves wanted, could escape a counter offensive. And this counter-attack did not come only from economic interests. The institutional and policy decisions during $1973 \mathrm{had}$ aroused opponents within the machinery of government.

The pressure to reverse the tariff cut was heightened politically by the worsening recession and rising unemployment. In retrospect, the counter-offensive may have also been made more difficult to resist because the tariff cut had been presented to the community primarily as an anti-inflation measure rather than as a move designed to bring substantial efficiency and productivity gains through industry resiructuring. This meant that the deteriorating macroeconomic climate could be used as a legitimate reason for reinstating protection.

The reinstatement, while not reversing the reductions across the board, took the costly form of quantitative import restrictions, in the form of GATT-legal tariff quotas, facilitated by Australia's lack of tariff binding commitments with its trading partners. These were initially intended to be temporary, to provide key industries such as PMV, TCF and steel with a breathing space. In reality, they became more or less a fixture for the next decade and a half, leading to an escalation in the effective assistance of the industries concerned (see Figure 3).

Throughout this period, Australia also heightened its administered protection by changing the rules on anti-dumping and concessional entry arrangements. Government procurement was increasingly used as a device for assisting local industry, both through preferential margins and offset arrangements with successful foreign tenders. Subsidies of various kinds also began to proliferate in the late 1970 s, with export assistance and production bounties predominating. The special arrangements for TCF and PMV spurred other industries to seek similar deals. Packages 
of assistance or industry 'plans' became fashionable for the lucky ones, while the others continued to have their tariffs reduced following IAC inquiries.

This 'backsliding' phase lasted nearly a decade, during which time the average effective assistance to manufacturing was flat or rising. By the mid-1980s, however, the plans were becoming more strategic, being reformulated to facilitate restructuring and greater export orientation. They nevertheless showed the marks of having been negotiated with representatives of the industries concerned (IAC, 1987). Change was gradual; financial assistance was forthcoming quickly, and pressure to adjust postponed.

The IAC continued to conduct inquiries into industry assistance, as well as monitoring developments in industry policy generally. In 1982, it completed a report for the government on Approaches to General Reductions in Protection, which were advocated as a more effective way of moving to a less distorted incentives structure. The government took no action at that time, indicating that it was:

Conscious that the capacity of the community to accommodate the economic and social consequences of such unilateral reductions is necessarily reduced in periods of subdued economic activity - and at a time when our exporters are facing increasing restrictions on their access to overseas markets. (cited in IAC, 1982:4)

In succeeding years, the depreciation of Australia's currency and better economic conditions made adjustment to lower protection easier. Indeed, the protective effect of the tariff quotas for PMV declined significantly, to the point where they were virtually redundant and could be removed in early 1988. This, together with the general reductions in tariffs that were finally instituted in that year, put Australia back on the liberalisation path, and the 1991 program gave it a greater impetus. Since then, it has been increasingly recognised that the era of protection is over, at least for most Australian industries.

But some things are never really over. With the demise of the tariff and continuing high levels of unemployment, there has been growing pressure on government to provide other forms of targeted support to industry. Over the last decade, the arguments for support have become increasingly sophisticated. Strategic trade theory was embraced by those promoting or sponsoring industry interests in the late 1980 s, as was the new growth theory in the early 1990s. Most recently, the concept of market failure, which was seen to have justified government support for R\&D, has been coopted for much broader duties, in the process distorting the concept almost beyond recognition.

A feature of the more recent push has been the role of special reports commissioned by representatives of industry interests. These have been intended to focus public attention, to provide persuasive arguments and to be seen to have more independence than the industry lobbies themselves. While this approach has been most in evidence recently, some may recall earlier efforts, such as the Pappas Carter report commissioned by the Australian Manufacturing Council (1990). 
Reports of this kind have generally attracted much favourable attention at first, especially in the media, but most have had little staying power because they are often seen to be self-serving or client-driven. Despite the growing sophistication in their language, they have generally been less sophisticated in their analysis and less than rigorous in what they present as evidence: anecdote and the personal observations of corporate executives usually loom large.

Of the recent crop of industry reports, the Mortimer Report stands out for its explicit recognition of the need to apply market failure and economy-wide tests to all forms of industry support (Review of Business Programs, 1997). The framework that Mortimer presents for doing this is, on the whole, sensible: indeed it has much in common with that suggested by the Industry Commission in its submission to that review (IC, 1997a; see also Gibbs \& Emery, 1998). One important benefit of this part of the Mortimer Report, therefore, is that it made it easier for government to reject the more narrowly targeted industry policy proposals in the other reports. Moreover, it may have also raised doubts about the value of some of Mortimer's own findings and recommendations, including that review's assertion that the current level of public spending on industry programs is 'about right', despite doubts expressed about their rationales, and the proposal for a discretionary fund to entice suitable investments to come to (or remain in) Australia (IC, 1997b).

A related development has been the increased use of economic consultants by industry lobbies. The quality of that work and its contribution to informed policymaking have varied enormously, depending on the nature of the client group and the qualities of the consultant. Public suspicion that 'he who pays the piper calls the tune' has sometimes affected the credibility of such work, however, even when undertaken by public sector agencies to satisfy external earnings obligations.

During the recent Industry Commission inquiries into assistance for PMV and TCF, industry-sponsored (or State government-sponsored) economic modelling had, for the first time, a central role in the debate. The Commission has for many years used Computable General Equilibrium (CGE) modelling to explore the economy-wide effects of trade liberalisation and other policy changes. Industry organisations came to recognise the power of such numbers in the policy debate. The modelling they commissioned, while lacking some of the sophistication and detail of the Monash Model used by the Industry Commission, was in most cases professionally done and contributed to our understanding of the potential impacts of further liberalisation.

Unfortunately, perhaps inevitably, the consultant's results were sometimes misused. A key instance during the PMV inquiry was the inference that protection added on average less than $\$ 100$ to the cost of a car, based on estimates of the static welfare (or consumption) loss rather than the consumer tax equivalent. As one commentator responded, in that case why not simply replace the tariff with a $\$ 100$ cash rebate to every purchaser of an Australian-made car? (Trebeck, 1997). But while the technical jousting in the battle of the auto models may have made great sport for the technically literate, it probably did more to confuse than enlighten decision-makers. This may well have contributed to the eventual policy outcome. 
It is of interest in this context to quote the reaction to the government's decision of the auto industry's chief modelling protagonist:

The recently announced approach to tariff reform in the car industry is a step in the right direction, in that cuts are continuing but at a more gradual rate. However, it would have been better if tariff reductions to 10 per cent in 2005 were achieved in small annual steps rather than one large step, and the situation after 2005 had been clarified. (Murphy, 1997:18)

Indeed, the situation after 2005 involves a number of uncertainties, not the least of which is the capacity of a future government to withstand political pressure to reverse the relatively large tariff cuts scheduled for that year, assuming that they are enacted. It is salutary to recall the pressure that was building prior to the Industry Commission's automotive inquiry for the current phase-down to be arrested. One unrecognised achievement of the recent decisions on PMV and TCF, therefore, has been to lock in the current programs.

A new element of uncertainty is the requirement that reviews of post-2005 assistance arrangements take account not only of Australia's APEC commitments but also of progress on market access. To industry, this will look like official recognition of its position (which it has argued during the two inquiries) that Australia's liberalising actions should depend on those of its APEC partners. This escalation of the notion of reciprocity through APEC is ironic, given that Australia managed to minimise its influence for so long under the GATT, and that APEC, in contrast to the GATT, is explicitly non-reciprocal in nature.

Australia can only lose from a strategy of waiting for other countries to "catch up' (if indeed they are behind) or using its remaining trade barriers as negotiating coin to prise open foreign markets. Two facts confound such a strategy. The first is that Australia gains much more from its own liberalisation than from that of other countries (see McKibbin, 1998, for an empirical assessment.) The second is that Australia lacks the bargaining strength needed for reciprocity games. Australia's interests lie in proceeding with reforms that make sense for domestic reasons, while encouraging other countries to do likewise.

\section{Looking Ahead}

The Prime Minister, John Howard, observed after the APEC meeting in Manila in 1996 that progress in implementing trade liberalisation depends on achieving greater awareness of the national benefits, to counter the public influence of those industries facing adjustment.

This recognises the reality that international rules and negotiations cannot, by themselves, generate the necessary domestic commitment to resist backsliding. That will depend on the ability within each country of policy-makers and institutions to maintain an economy-wide perspective, despite one-sided political pressure to resist reform. This has also been recognised by a number of eminent international groups examining the world trading system, including a review chaired by Olivier 
Long, former Director General of the GATT (Long et al., 1989) and the Leutwiler Report (Leutwiler et al., 1985). Finding a new international mechanism for pursuing politically more neutral domestic environments for trade liberalisation is no easy task. But a recent report by Alf Rattigan and Bill Carmichael (1997) rightly places this issue at centre stage.

Australia's own progress will depend on maintaining the open and relatively informed debate that it has had in the past. Our liberalisation experience demonstrates the importance of processes that can generate the wider information needed for nationally rewarding policy decisions. But it also highlights the pivotal role of our political representatives themselves, who are best placed to sell reform to the community at large, and whose attitudes and actions shape the environment in which the expectations of industry are formed. 


\section{References}

Anderson, K . \& R. Garnaut (1987), Australian Protectionism: Extent, Causes and Effects, Allen \& Unwin, Sydney.

Australian Manufacturing Council (1990), The Global Challenge: Australian Manufacturing in the 1990s, Melbourne.

Banks, G. (1992), 'Transparency, Surveillance and the GATT System', pp. 55-85 in M. Hart \& D.

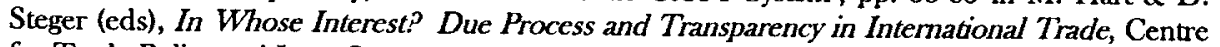
for Trade Policy and Law, Ottawa.

Bureau of Industry Economics (BIE) (1995), Impact of the CER Agreement Lessons for Regional Economic Integration, AGPS, Canberra.

Corden, M. (1996), 'Protection and Liberalisation in Australia and Abroad', Australian Economic Review, 2nd Quarter: 141-54.

Crawford, J. (1968), Australian Trade Policy 1942-1966: A Documentary History, Australian National University Press, Canberra.

Department of Foreign Affairs and Trade (DFAT) (1995), Winning Markets, AGPS, Canberra.

- (1997), In the National Interest: Australia's Foreign and Trade Policy, Canberra.

Gallagher, P. (1997), 'Objectives of WTO and broad negotiating framework', paper presented at Centre for International Economics, Symposium on Agricultural Trade Strategies, Canberra, 29 September.

Garnaut, R. (1994), 'Australia', pp. 51-72 in J. Williamson (ed.), The Political Economy of Policy Reform, Institute for International Economics, Washington DC.

Gibbs, I. \& P. Emery (1998), 'Reforming Australia's Commonwealth Business Programs', Agenda 5: 316.

Glezer, L. (1982), Taniff Politics: Australian Policy-making 19601980, Melbourne University Press, Melbourne.

Industries Assistance Commission (IAC) (1976), Multilateral Trade Negotiations - General Rates of Duty : First Report (Abridged Version), 30 January, Canberra.

- (1982), Annual Report, 1981-82, AGPS, Canberra.

- (1987), Annual Report, 1986-87, AGPS, Canberra.

Industry Commission (IC) (1995a), Assistance to Agricultural and Manufacturing Industries, AGPS, Canberra, March (Information Paper).

— (1995b), Annual Report 1994-95, AGPS, Canberra.

—- (1996), Annual Report 1995-96, AGPS, Canberra.

- (1997a), Submission to the Review of Business Programs, AGPS, Canberra.

(1997b), Annual Report 1996-97, AGPS, Canberra. 
(1997c), Trade and Assistance Review, 1996-97, AGPS, Canberra.

Leutwiler, F. et al. (1985), Trade Policies for a Better Future: Proposals for Action, GATT, Geneva.

Long, O. et al. (1989), Public Scrutiny of Protection: Domestic Policy Transparency and Trade Libcralisation, Gower for the Trade Policy Research Centre, London.

McKibbin W. (1998, forthcoming), 'Regional and Multilateral Trade Liberalization: The Effects on Trade, Investment and Welfare', pp. 195-220 in P. Drysdale \& D. Vines, Europe, East Asia and APEC: A Shared Global Agenda?, Cambridge University Press/Global Economic Institutions/Austalia-Japan Research Centre, Cambridge.

Murphy, C. (1997), 'The pace of tariff reform', CEDA Bulletin, July.

Rattigan, A. (1986), Industry Assistance: The Inside Story, Melbourne University Press, Melbourne.

\& W. Carmichael (1996), Trade liberalisation: A Domestic Challenge for Industrial Nations, National Centre for Development Studies, Australian National University, Canberra.

Review of Business Programs (1997), Going for Growth, Business Programs for Investment, Innovation and Export, AGPS, Canberra (D. Mortimer, chair).

Robertson, D. (1997), 'Reciprocity and Protectionism in Australia's Trade Policy', Agenda 4: 135-42.

Snape, R. (1984), 'Australia's Relations with GATT', Economic Record 60(168): 16-27.

- L. Gropp \& T. Luttrell (1998, forthcoming), Australian Trade Policy 1965-1997: A Documentary History, Allen \& Unwin, Sydney.

Trebeck, D. (1997), 'Reason to scrap car tarif', Australian Financial Review, 10 March.

Tumlir, J. (1983), 'International Order and the Decline of Multilateralism', an address to the Economic Society of Australia, Canberra, March.

(1984), Protectionism: Trade Policy in Democratic Societies, American Enterprise Institute, Washington DC.

This article is an edited version of a paper presented to the conference 'Backsliding from Trade Liberalisation Commitments', organised by The Australian National University's National Centre for Development Studies at Parliament House, Canberra, on 24 October 1997. The author is grateful to Paul Emery and Leanne Holmes for assistance in preparing the table and charts, as well as to several colleagues and to two referees for comments on an earlier draft. The usual disclaimer applies. 